International Journal of English Literature and Social Sciences
Vol-7, Issue-1; Jan-Feb, 2022
Journal Home Page Available: https://ijels.com/
Journal DOI: $10.22161 /$ ijels

Peer-Reviewed Journal

\title{
Re-thinking of Queer Voices in the New South Africa: Nadine Gordimer's None to Accompany Me
}

\author{
Dr. Chinyere T. Ojiakor ${ }^{1}$, Nkechi Ezenwamadu²
}

\author{
Department of English, Madonna University Nigeria, Okija Campus, Anambra State, Nigeria \\ Email: tcorjiakor@gmail.com \\ Asso. Prof., Department of English, Madonna University Nigeria, Okija Campus, Anambra State, Nigeria \\ Email: ezenwamadunkechi@gmail.com
}

Received: 20 Dec 2021; Received in revised form: 02 Feb 2022; Accepted: 10 Feb 2022; Available online: 17 Feb 2022

(C)2022 The Author(s). Published by Infogain Publication. This is an open access article under the CC BY license

(https://creativecommons.org/licenses/by/4.0/).

\begin{abstract}
In the midst of the ongoing changes, a complex social and economic life, contemporary South African society is characterised by exceptional complexity. The new South Africa following democratic rule and accompanying urbanisation had brought about drastic changes in the primary form and institutions in society. Post-apartheid literature foregrounds the themes of poverty, assault, rape, bloodshed, xenophobia, gay life and the AIDS epidemic amongst others. None to Accompany Me presents incidents of life experiences of young adolescents dealing with issues of sexuality, violence and social struggle. This study focuses on Nadine Gordimer rethinking her former conception of same-gender love and sexuality. A literary work exploring the contemporary social issues faced by many young people in modern society and investigates what the researcher see as a significant shift in her most recent work after independence. The paper is informed by an old-fashioned liberal humanist vision and clearly interprets escalated gay existence in post-apartheid South Africa not as a strange phenomenon but a logical maturation of the pressures of long years of racial segregation and oppression as well as the precipitated expectations of the post-apartheid era. The findings are that by asserting the queer subject and their place in post-apartheid South Africa, None to Accompany Me offers vital counter narrative to widespread homophobia. It sustains on the premise that for social justice and harmony to reign, there should be the political will of state leadership to shun cultural exclusionism and articulate policies that will reconcile and accommodate cultural, racial and sexual differences.
\end{abstract}

Keywords—Re-thinking, Apartheid, Family, Queer Voices, South Africa.

\section{INTRODUCTION}

What distinguishes post-apartheid literature from apartheid literature is primarily its thematic focus. Post-apartheid literature is a genre of literature that has evolved concurrently with post-apartheid South Africa, as this field of literature presents the problems of a more modern South African life. In every human society, there is the tendency and temptation for one group to think that it is superior and more important than the others. In fact, this tendency is very visible in racialised and ethnocentric societies where one culture, race or individual predilection tends to dominate the others. The former U.N Secretary-General,
Kofi A. Annan in his 2001 Nobel Lecture, condemned this cultural chauvinism in the contemporary society avowing that: "We recognize that we are the products of many cultures, traditions, and memories; that mutual respect allows us to study and learn from other cultures; and that we gain strength by combining the foreign with the familiar" (162). By this declaration, Kofi Annan shows that the world would be a better place when people embrace cultural tolerance since no culture is perfect and self-sufficient. In societies where cultural chauvinism exists, there is bound to be racial or ethnic antagonism which, if not nib in the bud, could result to full-blown 
conflict. As Kofi Annan further opines, although one has the natural right to take pride in one's cultural heritage, "the notion that what is "ours" is necessarily in conflict with what is "theirs" is both false and dangerous. It has resulted in endless enmity and conflict, leading men to commit the greatest of crimes in the name of a higher power"(162). Nevertheless, this problem could be averted in societies with tough legal dispositions against cultural assimilation. Consequently in the midst of its sociohistorical, cultural and racial backgrounds and in order to forestall the trauma of the past, the post-apartheid South African leadership is making conscious effort to enact laws that will reconcile cultural differences among its citizens. It follows, therefore, that for social and political harmony to exist in this society cultural diversity and dialogue must be encouraged. The new Constitution of the Republic of South Africa (1996) is one of the very few Constitutions that refer to sexual orientation as something that should not be discriminated against. It declares that "equality includes the full and equal enjoyment of all rights and freedom," and "no person may unfairly discriminate directly or indirectly against anyone on one or more grounds," including "sexual orientation" as well as "race, gender, sex, pregnancy, marital status, ethnic or social origin, conscience, belief, culture, language and birth" (Chapter 2 ). In response to the socio-political changes writers have logically shifted their focus from apartheid political issues to a wider dimension of other issues faced by South Africans in this era of democracy. This paper expounds on the interconnections between literary discourse and ideological perception by showing that writers are ideological beings who do not only say what society is but also what society should be. As the case maybe, most writers use literature as an aperture to propagate their ideological visions of life; so literature becomes grossly political and presents itself as an arena for ideological contestation and projection. Louis Althusser expressively spells out that artistic texts cannot be devoid of authorial ideology and the society from which they emanate. Althusser, further, contends that "When we speak of ideology, we should know that ideology slides into all human activity, that it is identical with the "lived" experience of human existence itself..." (1481), consequently, it follows from a syllogistic perspective that art being a creative human activity cannot be dissociated from ideology. Althusser iteratively says:

I believe that the peculiarity of art is to 'make us see', 'make us perceive', and 'make us feel' something which alludes to reality ... What art makes us see, and therefore gives us in the form of 'seeing', 'perceiving', and 'feeling', is the ideology from which it is born, in which it bathes, from which it detaches itself as art and to which it alludes (1480).

As a matter of fact, the analysis of None to Accompany Me ascertains that for social justice, peace and harmony to reign in multicultural and multiethnic societies like South Africa, there should be conscious effort from the political leadership to shun cultural exclusionism and legislate laws encouraging unity in diversity. Whereas, formerly, the family constituted the basic unit of society, the modem urbanised family according to Pretorius, "has changed to a group of people having fleeting contact, people who live a complicated life-in-multiplicity and who are characterised by impoverished communication between its members" (102). Pre-independent South Africa was stable albeit the Apartheid constructions, simple and undifferentiated. The extended family was the most significant form of society as the basic economic unit, within which the various family functions were actualised. Same-sex desires and queer realities were consequently almost never represented in published literature during apartheid, even when a Nigerian Bisi Alimi says otherwise when he claims that, "in digging up facts, I found that, while many Africans say that homosexuality is un-African, African culture is no stranger to homosexuals behaviours and acts" (313). While these voices have found expression in post-apartheid South Africa, there are still notable racial divides, and very few queer characters and authors are included in discussions of recognised post-apartheid literature.

None to Accompany Me, the offspring of today's complex urban realities world-wide, represents one of our global family's most serious, urgent and rapidly growing Socioeducational challenges. The contemporary family is influenced by a complex social, economic and cultural environment which has a dynamic influence on its members. Amidst such a complex and dynamic society with constantly changing norms and values, it has become increasingly difficult to equip children adequately. Harmful and inhibiting social influences inundate and overpower the family situation, to such an extent opines Le Roux "that parent and child have become engaged in a struggle between familial and social influences" (83). The end of apartheid in the world of the novels then appears as an era of some kind of sexual "libertinage" where sex has no limits just like in the animal world. The Prohibition of Mixed Marriages Act of 1949 and the Immorality Act of 1950 made sexual relations and marriage between persons of different races a criminal offence. With the abolition of apartheid, these laws were also abolished. One is forced to wonder whether the abolition of sex prohibition laws have something to do with escalated cases of rape, uncontrolled sexual behaviour and the spread of HIV/AIDS that have seemingly enveloped the post-apartheid South African 
society. A rural community life style has become an urbanised, impersonal, formal, businesslike way of life more so, family structure in particular.

\section{Gay Writings and Voicing Silences}

Scholars like Cheryl Stobie and Brenna M. Munro have done detailed, extensive studies of many South African texts representing queer realities, this paper will build on their work to investigate representations of queer characters in novels and how these texts function within and respond to historical context in recent years. The role of queer rights and queer visibility had always been contentious during apartheid. Sheila Croucher explains that "policing of sexual minorities was consistent with repressive apartheid ideology" (317) and opposition to repressive legal frameworks was scattered since the gay organisations within the country were divided, and "a staunchly apolitical stance continued to characterise white gay South Africa" (317). Although various queer groups existed, they were still racially divided, which resulted especially in the silencing of most queer voices. Alimi contends that the assertion that gay life is un-African is,

used in South Africa to rape lesbians. It is used to pass laws and to jail, threaten or kill gay rights activists. It is used to dehumanise LGBT people across Africa and legitimise the hate that we face. It is the reason I receive death threats, which ultimately drove me into exile from my home in Nigeria (314).

Additionally, these gay organisations were mostly unwilling to outright oppose apartheid. The Delmas Treason Trial in 1985 saw one of the most important conflicts within the liberation movement with regard to gay rights, as Simon Tseko Nkoli, a gay man and United Democratic Front activist, was among the twenty-two people charged with treason. Thoreson explains that "Nkoli publicly insisted upon the inseparability of the struggles against apartheid and homophobia, challenging his comrades in both movements to fight together" (680). One of the few gay organisations in the country at the time, the mostly white Gay Association of South Africa (GASA), decided not to support Nkoli, himself a member of GASA, during the treason trial. GASA received local and international scorn for the stance of trying to remain 'apolitical' in the face of the injustices of apartheid.

Another form of silencing was found in the paternalistic censorship during apartheid. Queer fiction under apartheid faced severe censorship, and likewise queer visibilities were socially shunned, to the point where representations of queer lives were almost nonexistent in the country. For example, Michael Power's 1972 novel Shadow Game, about an interracial love affair between two men, was banned despite positive international reception. Furthermore, even though it was not banned, J.M. Coetzee's novel In the Heart of the Country (1977) depicting samesex desire between the white character Magda and the black farm worker Klein-Anna, emerged as one of Coetzee's least-discussed novels, and the queer elements in the text were according to Chiara Briganti, "almost completely ignored by critics at the time" (42). This again indicates a type of silencing and the obscuring of a text that depicts queer themes. It was only after the unbanning of the ANC and other political parties, a moment which signalled the fall of formal apartheid, were queer voices given more space to find expression. Due to legal and social changes during the 1990s, these previously marginalised realities were finally given the chance to reach mainstream audiences. Transgressive and diverse voices were celebrated, and queer literatures were being released by major publishers. What emerged was literature that gave nuanced, sensitive portrayals of queer identities and experiences within South Africa. In post-apartheid South Africa, even though the majority of South Africans still seem to be vehemently homophobic, given the stance of the Starks, a space was created for queer voices to find large-scale expression and for queer realities to be a part of the "Rainbow Nation," a phrase which Munro notes "encodes the intersection of multiculturalism and gay rights" (vii). Munro explains that public opinion in the early 1990s saw the acceptance of gay people as symbolic of a discourse of freedom which had swept the country, and that representations of queer lives were in some ways embraced because "the idea of gay rights made South Africans feel modern and magnanimous as they watched, or took part in, multiple dramas of acceptance" (xxiv).

This paper is therefore not comprehensive, and does not explore every instance of queer literary representation; instead, the text has been selected to demonstrate some of the dynamics of cultural and sexual identities in South African fiction. These representations in novels can provide an intimate look at how these characters understand their identities and their sense of belonging within contemporary South Africa. When read within the context of the 'silencing' inherent in apartheid structures and rigid traditionalist cultural mores, they offer the opportunity for voicing realities which are often suppressed and not entirely new.

\section{A Society at Pains to Reconcile Itself after Decades of Racial Animosity}

Gordimer was born in South Africa in 1923 and her parents were Jewish émigrés - her mother from England and her father from Latvia. She has remained in South Africa, having lived in Johannesburg since 1948 until the 
5th of December, 2015 when she died. She was educated in an all-white covenant school and spent a year at Witwatersrand University after which her life has been dominated by writing which won her the Nobel Prize for Literature in 1994. Prior to 1990, Gordimer's prominent anti-apartheid views in her fiction earned her a reputation as a public intellectual. However, since the coming to power of the ANC, she has ceased to challenge key national issues. She then had to tailor her thematic preoccupations to suit the new socio-political context. Ulrike Auga explains that:

With the negotiated settlement heralding a nationstate democracy and market economy and later neoliberalism, notable shifts occurred in ANC policy. In line with these shifts, Gordimer became the house critic of post-apartheid South Africa. Such a stance entails the legitimation and stabilization of the system. Gordimer became the legitimizing intellectual, a role that has been part of the institution of national unity, democracy, and the market economy ever since the French Revolution (209).

In this decade of transition to Democracy, this South Africa's most celebrated writer published a novel that tells the story of white, middle class, middle-aged Anglo- South Africans whose struggle to adjust to the new era includes dealing with the revelation that their children are not heterosexual. The depiction of legibly gay characters is something of a departure for this straight-identified writer and the fact that she took on this theme indicates its salience at the time; her subsequent works has not included queer characters in form and manner of the kind of representation as in the novel under the present study. This novel of South African political life explores relations between politics and the way people conduct their personal lives. It parallels two families, the Starks and the Maqomas. Vera Stark, the novel's central character, is a lawyer for the Legal Foundation, and her success in settling black Africans' land claims leads to a seat on the important Technical Committee on Constitutional Issues. For her, politics is like art-transcendent-leading to estrangement from her husband, Ben; her lesbian daughter, Annie; and her son, Ivan. Sibongile Maqoma's rise to political prominence is even more spectacular than Vera's, but she remains with her husband, Didymus, in spite of the strains caused by his political eclipse and her rise. . The great impact those years of transition had on the private lives of South Africans is shown by the example of these two couples, a white and a black one, whose personal fates are, interweaved with events and atmosphere. In the novel, the white couple, Vera and Bennet Stark, organise a party to celebrate their wedding anniversary in "... the year the prisons opened" (5). The party at the Starks is also attended by members and colleagues of the Legal Foundation as well as people from different activist groups. As the omniscient narrator underscores that,

white men and women who had been active in campaigns against detention without trial, forced removal of communities, franchise that excluded blacks: students leaders, ganged up under a tree in the garden drinking beer from cans, who had supported striking workers: a couple of black militant clergymen and an Afrikaner dominee excommunicated for his heresy in condemning segregation : a black actor who hid and treated young militants injured in street battles with the police and army: black community leaders who had led boycott; one or two of the white eternals from the street meetings of the old Communist Party who had survived many guises ( 5-6).

The celebration of their wedding anniversary in this year when "the prisons opened", after many uncelebrated ones, has a political undertone; it is more of celebrating the official end of apartheid, racial segregation and all silenced voices since this white couple were uncompromising activists against the apartheid system. In the context of social semiotics, the party signifies the celebration of the end of apartheid and the introduction of socio-cultural pluralism and freedom for the oppressed in South Africa with the release of prisoners from jail, which shows the triumph of the new South Africa over exclusionism and cultural hegemony in South African society. This year can be situated within the context of 1990 when Nelson Mandela and other apartheid activists were released from jail thereby bringing the apartheid saga to an end. Before now, the third-person omniscient narrator argues that this couple,

have been married so long they didn't usually make an occasion of the recurrent day; but sometimes it suggested an opportunity to repay invitations, discharged all we owe in one goal, as Vera says, and on this year of all years it seemed a good excuse to go further than that: to let themselves and their friends indulge a little in the euphoria they knew couldn't last, but that they were entitled to enjoy now when, after decades when they had worked towards it without success, change suddenly emerged, alive from entombment (5).

The dignitaries to this party are from all races and classes of people. The party, metaphorically, represents a prototype of the envisaged new South Africa which will accommodate people from different races, classes and 
cultures in the spirit of cultural and racial tolerance. Furthermore, the party provides an occasion for South Africans to express their desire to be liberated from the claws of apartheid. In a vivid description, the narrator says, "music began to shake the walls and billow out into the garden; political argument, drinking and dancing went on until three in the morning" (6). The people now are free to express their views and ideas on issues which concern their country without any fear of spies or police brutality. This explains why Vera's divorced husband can visit her at ten o'clock at night with "no fear of muggings back in those days in the Forties" (7). This contrast between the present and the past has been drawn to vindicate the idea that there is relative freedom and security in present South Africa because of the optimistic vision of the anti-apartheid white regime. The anti-apartheid white regime in None to Accompany Me further shows its predilection for tolerance when it grants general armistice to all exiles to return to South Africa. They are given a rapturous welcome by the crowd which had been waiting in the airport. The omniscient narrator captures this scenario using vivid description thus:

The plane-load of returning exiles who were arriving every few days were awaited at the airport by chanting and dancing crowd; when they came through the automatic doors that closed behind them on the old longing for home, when they emerged pushing squeaking chariots charged with the evidence of far places carrying airport store giant teddy bears, blind with excitement in the glare of recognition - not at once, of who they were individually but of what they stood for, the victory of return - a swell of women's ululating voices buffeted them into the wrestle of joyous arm. Children seen for the first time were tossed from hands to shoulders, welcome banners were trampled waved, bull-horns sounded the hugging capering procession of transit to repossessing life regained, there outside the airport terminal was a carnival beyond belief it would ever be possible to celebrate. Home: that quiet word: a spectacle, a theatre, a pyrotechnic display of emotion for those who come from wars, banishment, exile, who have forgotten what home was or suffered not being able to forget (43-4).

Cross-cultural interaction is also found in the comportment of the characters. In None to Accompany Me, the post-apartheid white regime comes to self-realisation that blacks are also capable of doing things that whites can benefit from. In the text, the Starks and other whites attend the opening ceremony "of an exhibition of painting and wood carving by black artists". In cultural studies, it is said that art, in general, is not only an expression of beauty but also the reflection or carrier of the culture of a people. This exhibition of African art truly symbolises the beauty of the African culture and also shows that creativity is not the monopoly of the white race; that blacks are also very creative. The narrator further remarks that the artefacts and craftsmanship of these black artists "had become fashionable" because "city corporations and white collectors had seen such acquisitions as the painless way to prove absence of racial prejudice" (73). These African artefacts are, therefore, semiotic resources and the interest shown by whites in them shows that they acknowledge African culture in its essence and existence and communicate the truth that something good can also come from Africa. Around these parallel stories, Gordimer weaves the complex, shifting, volatile political fabric of South Africa's perilous state: terrorist violence by both whites and blacks, crime, competing land claims and the dangers they entail, and the country's pervasive racial tensions. The most compelling of these are the pictures of the country's acute housing shortage - the ramshackle villages, overcrowded apartments, and suburban neighbourhoods shifting from white to black ownership. Gordimer harbours no illusions about the political and social differences facing the new government. If anything, the personal stories emphasize how complex these problems are, how difficult it is and will be for the new government to keep peace and pursue justice.

\section{Narrativity: Unpacking of Private Selves}

In all its experimental delineations, None to Accompany $M e$ explores sexuality in terms of the transformation of private selves. Gordimer introduces a lesbian theme for the first time in this novel and envisages new types of daughters in her delineating of lesbian sexual identity. In her earlier novels, she complies with the stereotypical constructions of homosexuality and lesbianism as related to freak sexuality, personality disorder or emotional disturbance in her unconscious representations of sexual identity. A deviant daughter, Maxine, in her short story, 'Siblings', in A Soldier's Embrace (1980), uses lesbianism as a pretext for enigmatisng herself in order to distance her from her white middle- class family. Maxine is described as a self- outcast who "could find no place for her" (39) and cuts off her ties both with her family and the world. After victimising her family through many suicide attempts and arrests on drug charges, she afflicts them by boasting that she now lives a lesbian. Another example of homosexual identity in Gordimer's work is Terry in The Conservationist (1974), the farm owner Mehring's homosexual son. Homosexuality in this novel is a metaphor for the sterility of the white man's line in Africa, which contrasts significantly with the black's resilience in 
their land. Mehring's line becomes extinct when Terry leaves South Africa to live with his divorced mother in New York and never returns to his country. His sexual orientation can be read as symbol for the heirless white civilisation in Africa as represented by Mehring's leftist mistress: "And if I had children, I don't believe in inheritance of property, unearned possessions, the perpetuation of privilege" (77). Gordimer grants no tenure of African land to the white landowner, Mehring, who in the end gives up both his family and his farmland. Both Terry and Maxine exemplify social deviance, both could find no place in their society and have very weak ties with their family. Gordimer's earlier work thus reproduces the traditional marginalisation of homosexual and lesbian children as alienated and demonic Others.

While Gordimer's earlier treatment of homosexuals stereotypes them as marginal Others, bereft of home and family ties, the lesbian daughter in None to Accompany Me are afforded the potentials of creating a new kind of home. Annick and her girlfriend, Lou, are well- integrated members of the new South African society. Within the transitional context of the emergent country, it is even possible for the couple to openly declare themselves as lesbians. They become new parents by adopting a formerly unloved and abandoned black female baby. They are depicted as an unconventional but ideal couple. Lesbianism in the novel is a new lifestyle rather than a pathological manifestation of sexuality. Here, Gordimer renders the lesbian couple into a constructive family unit. The picture of the white mother raising a black daughter and dreaming of a rainbow family is carried over from $A$ Sport of Nature and it now projects a new concept of parenthood and family structures beyond according to Celia Kitzinger, "the differences of race, gender and sexuality" (44). It is paradoxical that while the white heterosexual mother, Vera, leaves her nuclear family to live as a tenant, her lesbian daughter and her lover are making a new kind of home on their own terms. The narrative suggests that Annick is another new being who "grew and changed and moved into another self" (157). The creation of this new being as lesbian parent for the first time in her work clearly indicates the authors changing and growing awareness of sexuality and her new perception of lesbianism. The new daughters represent the author's re-definition of lesbianism as "sexual freedom" (273) and an alternative lifestyle, which opens up the possibility of a new home.

Gordimer's renewed sexual awareness, however, does not involve a full appreciation of sexual diversity. What is still problematic about her treatment of the lesbian theme is that Annick's sexuality is attributed to her fear of men because her mother was "taken away", the nest of home broken into by a man" (273). Vera blames herself for her daughter's sexual identity: "what did I do to put you off men?" (159). Although Gordimer offers the lesbian daughter the "free choice" (273) of love and the opportunity of creating new family ties, the novel still closets lesbianism as an abnormality for which a cause is sought and for which the mother is blamed within the heterosexual framework of taboos.

As we have seen earlier, Vera later revises her initial view of the sexual act as the exchange of the burdens of self and comes to recognise that "the various aspects of self cannot be placed all upon one person" (276). Likewise, the various aspects of female sexuality cannot be defined only in terms hetero-sexual norms. The fact that the novel projects the lesbian couple as new parents, who are making new kind of home, suggests that Gordimer is just beginning to revise her perceptive on homosexual love and sexual behaviour as a new form of freedom and new possibility in South Africa.

The lesbian theme in None to Accompany Me reflects a new release of creative thinking on all the transformations possible in the order of the new South Africa Constitution (1996). She suggests that sexual choices can be made part of the definition of freedom and that it is just as much a political subject as the official constitution that would legitimate a non- racial order. Her re-thinking of sexuality, gender and politics in None to Accompany Me leads inevitably to new conceptualisation of home in South Africa. The new concept of home is explored for each character both in their personal life and in the altering state. The female characters in particular emerge as new subjects through their commitments to creating a new home.

\section{CONCLUSION}

Gordimer's novel provided a powerful template of queer voice wrestling with identity in the democratic South Africa, and many of the later texts echo the tensions which the daughters raised. However, the changing representations of queer characters show a sense of a more accepting social climate, even when there are recurring moments of homophobia and unease around same-sex sexualities. The exploration of new concepts of home and the alternative sexuality as personal freedom have become possible in None to Accompany Me by the very potential unleashed by national liberation. The way that characters wrestle with the assumed conflict between their society and their same-sex desires in this text is important, as it shows recognition of the previously ignored and suppressed queer identities and also demonstrates how significant the recent representations are in confronting 
social values and reflecting on social change. The possibility of freedom is real and palpable and the narrative explores its true meaning. This possibility, with all its tension, betrayals and tragedies, is explored and delineated particularly in terms of new concepts of home on both political and personal levels because, in South Africa, where the public and the private are intricately interlinked, "perhaps the passing away of the old regime makes the abandonment of an old personal life also possible" (315). Annick and Lou signal a very decisive shift in queer representations, in that their sexuality is shown to be significant in the text, but causes much less conflict for them than demonstrated in earlier texts. Yet, even though they are less conflicted, face less public resistance, and are therefore less afraid of expressing themselves and demonstrating their affection, the future of queer representation need further acknowledgement of changing attitudes in South Africa. There is still much space for representations which assert the voices of queer individuals, be they authors or characters in texts.

\section{REFERENCES}

[1] Auga, Ulrike. "Intellectuals between Resistance and Legitimation: The Cases of Nadine Gordimer and Christa Wolf ", Texts, Tasks, and Theories: Versions and Subversions in African Literatures 3. Ed. Tobias Robert Klein et. al. New York: Rodopi, 2007. 191-212.

[2] Annan, A. Kofi. "Strategies for World Peace: The View of the UN Secretary-General". Global Issues. $21^{\text {st }}$. Ed. Robert M. Jackson. Ed. McGraw-Hill: Dubuque, 2006. 161-163.

[3] Althusser, Louis. "A Letter on Art in Reply to Andre Daspre." Norton Anthology of Theory and Criticism. Ed. Vincent B. Leitch. New York: Norton, 2001. 1480-1483.

[4] Briganti, Chiara. "A Bored Spinster with a Locked Diary: The Politics of Hysteria in In the Heart of the Country." Research in African Literatures Vol. 25, No. 4, Winter 1994, pp.33-49.

[5] Bisi Alimi. "If You Say Being Gay is not African, You Don't Know Your History." Wednesday 9 September, 2015 07.30 BST.

[6] Brenna M. Munro. South Africa and the Dream of Love to Come: Queer Sexuality and the Struggle for Freedom. U of Minnesota P, 2012.

[7] Croucher, Sheila. "South Africa's Democratisation and the Politics of Gay Liberation." Journal of Southern African Studies Vol. 28, No. 2, 2002, pp. 315-30. DOI: https://doi.org/10.1080/03057070220140720.

[8] Cheryl Stobie. "Postcolonial Pomosexuality: Queer/Alternative Fiction after Disgrace". Current Writing: Text and Reception in Southern Africa. Vol. 21, No. 1-2, 2009, pp. 320-41. DOI: https://doi.org/10.1080/1013929x.2009.9678324.
[9] Nadine Gordimer. The Conservationist. London: Jonathan Cape. 1974.

[10] _ A Soldier's Embrace. London: Jonathan Cape. 1980

[11] None to Accompany Me. Harmondsworth: Penguin. 1994.

[12] Ryan Richard Thoreson. "Somewhere Over the Rainbow Nation: Gay, Lesbian and Bisexual Activism in South Africa." Journal of Southern African Studies. Vol. 34, No. 3, 2008, pp. 679-97. DOI: https://doi.org/10.1080/03057070802259969.

[13] South Africa. The Constitution of the Republic of South Africa. N.P. 1996. www.Sahistory.org.za 